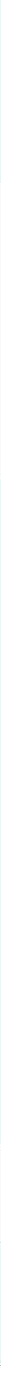

\title{
e a ficção nos \\ jornais: \\ ironia, humor \\ e visualidade
}

JOSÉ ALCIDES RIBEIRO

JOSÉ ALCIDES RIBEIRO

é professor de Literatura

Brasileira na USP e autor

de Imprensa e Ficcão

no Século XIX: Edgar

Allan Poe e a Narrativa

de Arthur Gordon Pym

(Edunesp). 
Gandelman (1986, p. 187) observa que toda pintura ou escultura, mesmo aquela inserida numa estética da ordem como a clássica ou neoclássica, se contemplada com muita proximidade, revela uma desordem, pois a visão microscópica percebe a granulosidade dos pigmentos ou a distribuição dos cristais do mármore. Após isso, o autor indica que o Impressionismo dá legitimidade e instaura o jogo entre a ordem e a desordem ligado à distância focal. Gandelman (1986, p. 187) comenta também que o Impressionismo é a hipóstase do olhar pousado sobre a tela num nível microscópico. São justamente as imagens microscópicas, paisagens ou cenas humanas, descritas com base na percepção ligada aos órgãos dos cinco sentidos, que dão a $O$ Ateneu a sua profundidade cognitiva e psicológica.

A leitura de $O$ Ateneu, na Gazeta de Notícias, revela, sem dúvida, essa espécie

PRESENCAA DO PADRÃO NARRATIVO DO ROMANCE SERIADO
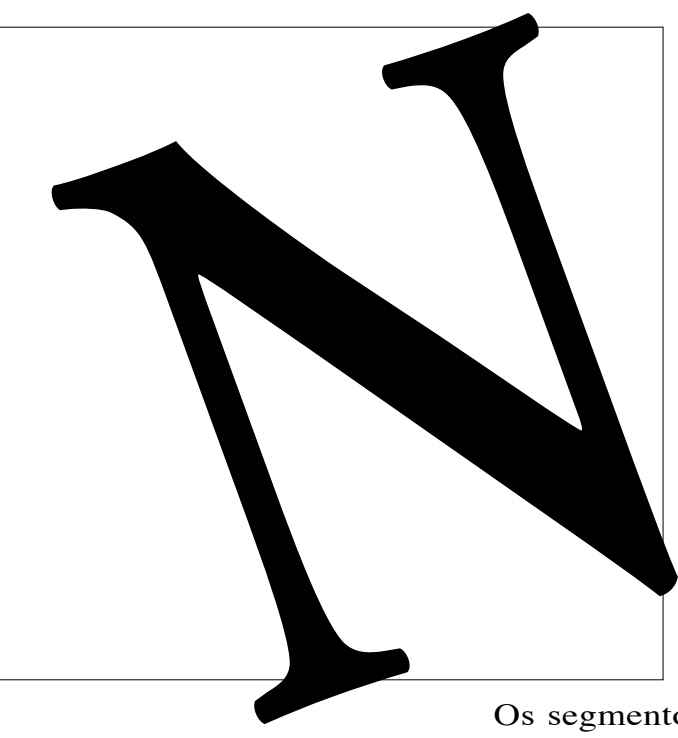

o dia 4 de maio de 1888 , a Gazeta de Notícias apresenta, na primeira página na parte superior, lado esquerdo, um anúncio destacando que irá iniciar, no domingo, a publicação do romance $O$ Ateneu, $\mathrm{Crôni}$ ca de Saudades, romance original de Raul Pompéia, em forma de folhetim. $\mathrm{O}$ romance começa a ser publicado em 8/4/1888 e termina na segunda quinzena de maio.

Os segmentos aparecem sempre ocupando a parte superior, lado direito da primeira página, passando às vezes para a segunda página. No período de publicação de $O$ Ateneu, Raul Pompéia disputa a atenção dos leitores com Xavier de Montépin, que tem editado o romance $A s$ Tragédias de Paris na parte inferior da primeira página. de jogo entre a ordem e a desordem no nível da macroestrutura do enredo. Por um lado, pode-se notar que em cada segmento a evolução da intriga do romance apóia-se no relato de um conjunto de episódios ligados às ações das personagens. São episódios dinâmicos, articulados de modo a criar um impacto na atenção do leitor. Aqui é clara a ligação com a estética do romance seriadoe faz-se evidente um movimento de ordenação e de evolução linear. Já por outro lado, evidencia-se continuamente uma quebra na evolução linear do relato por causa do registro microscópico das percepções da consciência de Sérgio sobre o mundo do colégio. Tal registro concretiza-se sobretudo por meio de sumários ou digressões.

$\mathrm{Na}$ verdade, tal movimento de ordem e desordem narrativa acontece por causa da influência do próprio instrumento de difusão, o jornal, utilizado para a veiculação de $O$ Ateneu. Como autor de ficção em jornal, Raul Pompéia não podia dissolver totalmente o padrão ficcional do relato de ações de personagens. Apesar disso, rompe profundamente com essa tradição, explorando uma espécie de narrativa impressionista, centrada no registro da subjetividade e exploradora do ponto de vista interno da personagem principal. 
Sobre o conjunto de técnicas de construção ficcional, resultante da contaminação da atmosfera de linguagem e do meio técnico do jornal, remeto o leitor para a leitura do livro Imprensa e Ficção no Século XIX: Edgar Allan Poe e a Narrativa de Arthur Gordon Pym, de minha autoria.

O estudo da mecânica dos cortes com gancho na publicação parcelada de $O$ Ateneu, na Gazeta de Notícias, revela a preocupação de inserir em cada segmento alguns episódios dinâmicos, que não se repitam. Evidência dessa preocupação é, também, o emprego de algumas técnicas de construção ficcional ligadas ao padrão narrativo do romance seriado. Para não cansar o leitor com um acúmulo de detalhes, comentarei os dois primeiros segmentos e o penúltimo do romance.

O primeiro segmento apareceu no dia 8 de abril de 1888 , página 1 . Vai do início do Capítulo I até o seguinte parágrafo: “Oh! Que não seria o colégio, tradução concreta da alegoria [...] das almas jovens no ritual austero da virtude". Aqui se pode notar uma abertura típica de romance seriado. A seqüência do relato do episódio da festa de encerramento dos trabalhos dos alunos e a caracterização hiperbólica de Aristarco, já introduzindo aspectos de comicidade, dão ao segmento um cunho atraente e sensacionalista. A interrupção do segmento é feita na passagem que reproduz o deslumbramento de Sérgio com o colégio, realizando-se o corte num ponto que produz curiosidade quanto à continuidade da história.

O segundo segmento continua com os aspectos explorados no primeiro. Foi publicado em 9/4/1888, o corte é feito no final do Capítulo I. Duas grandes seqüências dão base à estrutura do segmento, uma delas ligase ao episódio da festa de educação física, a outra consiste no diálogo de Sérgio e do pai com Aristarco. O último parágrafo delineia o perfil hiperbólico de Aristarco, que é definido como "[...] o homem sanduíche da educação nacional [...]” em virtude da exagerada eloqüência publicitária.

O penúltimo segmento apareceu em 13/5/1888, principia no início do Capítulo XII e termina em: "E fora preciso que sou- besse ferir o coração e escrever com a própria vida uma página de sangue para fazer a história dos dias que vieram, os últimos dias...". Aqui se pode notar um típico corte com gancho que provoca muita curiosidade em relação ao desenlace da história.

Raul Pompéia publica o seu romance num jornal bastante lido no Rio de Janeiro. Embora ainda mantendo o modelo francês das quatro páginas, o editor da Gazeta de Notícias insere uma gama variada de matérias no jornal: notícias sobre o problemático saneamento básico do Rio de Janeiro (falta de água, etc.), notícias policiais, seções típicas de almanaque, poesias, seções de romances seriados nacionais e europeus.

\section{A CONTAMINAÇÃO DO CONTEXTO DO JORNAL NA TEMÁTICA DA OBRA}

A observação das múltiplas atividades de Raul Pompéia revela um duplo perfil de literato e de jornalista. Da mesma maneira que muitos escritores da segunda metade do século XIX, Raul Pompéia atuou assiduamente em vários jornais cariocas. Foi colaborador da Gazeta de Notícias e da Gazeta Literária, redator no Jornal do Comércio, dos folhetins semanais "Aos Domingos" e "Lembranças da Semana”, participou como redator do periódico A Semana e trabalhou também na Gazeta da Tarde.

Na Gazeta de Notícias, Raul Pompéia publicou a novela As Jóias da Coroa. Além de ser um jornal de renome e de grande circulação, esse periódico era conhecido por agregar personalidades de projeção ligadas ao campo literário e ao jornalístico. Do mesmo modo, era conhecido, também, por publicar romances seriados. Na revista paulista Comédia, lançou vários contos sob o título "Microscópicos".

Para a Gazeta da Tarde, Raul Pompéia escreveu vários contos e uma série de meditações agregadas em torno do título "Alma Morta". 


\section{ESTRATÉGIAS DE MOTIVAÇÃO DO LEITOR DE JORNAL: TEMÁTICAS SOCIOCULTURAIS E BIOPSÍQUICAS}

É perceptível a exploração de duas temáticas gerais que se entrelaçam indissoluvelmente no desenvolvimento da intriga do romance. Uma delas tem como núcleo central a visão da escola como instituição que reflete, no microcosmo da vida quotidiana, as relações de poder e de dominação de uma determinada sociedade, no caso, a brasileira do século XIX. As condensações cronotópicas são inúmeras e bastante evidentes, bastando citar aqui que a ocupação dos espaços pelos personagens do romance vem geralmente contaminada por uma hierarquização vertical, cujo topo tem por centro a casa de Aristarco e, lateralmente, o chalé, que é o espaço reservado aos jovens que se aproximam da idade adulta.

Nessa primeira temática, nota-se uma proximidade de Raul Pompéia com a narrativa da ficção seriada. É de conhecimento geral que uma certa vertente desse tipo de ficção, entre eles, Eugène Sue, procurava explorar assuntos ligados às questões sociais que atraíssem e fisgassem o leitor para a continuidade da leitura. Aqui a temática ligada à vida educacional oferece farto material ficcional para estufar a intriga e satisfazer a curiosidade do leitor. Proveniente dessa temática, nota-se a técnica de explorar, em cada capítulo, episódios ligados a uma ou mais personagens, havendo uma fixação no relato das causas e efeitos das suas ações. São tendencialmente cenas cujo modo narrativo aproxima-se bastante da ficção seriada; observe-se aqui que tal modo de contar convive com um outro que é digressivo, concentrado em sumários (resumos) e que se liga à segunda temática.

A segunda temática aborda a problemática da evolução do processo psíquico de individuação do adolescente, centrando-se nos desdobramentos dos conflitos de Sérgio. Focaliza-se e delineia-se profundamente o perfil psíquico de Sérgio, resultante da vivência e da interiorização dos mapas simbólicos ligados à faixa biossocial da existência; signos simbólicos resultantes da microestrutura do sistema social organizado por Aristarco e materializados nas leis, regulamentos escritos ou orais, princípios morais, éticos, sexuais e comportamentais. Acaracterização da evolução de Sérgio tem porbase a trajetória existencial que se inicia com a perda do éden familiar e da ilusão da imagem do colégio, como fraternidade solidária, e chega ao desenlace no episódio do despertar para a função sexual masculina, concentrada na atração por Ema, mulher de Aristarco.

\section{COMICIDADE E IRONIA EM 0 ATENEU}

Podem-se notar duas grandes constantes em uma boa parte das narrativas da imprensa periódica brasileira: uma delas é a presença da utilização de técnicas de construção ficcional, resultantes da contaminação da atmosfera de linguagem e do meio técnico do jornal; a outraé a presença da comicidade que tem como alicerce principal a ironia. Provenientes da tradição das formas jornalísticas de pequena ou grande circulação, no século XIX, tais constantes dão à ficção brasileira uma feição própria.

Presente na tradição satírica dos numerosos pasquins da primeira metade do século XIX, a vertente da comicidade irônica pode ser notada nos romances publicados em jornais e revistas da segunda metade; o interesse no estudo dessas técnicas de construção ficcional no ambiente do jornal reside no seu poder de tornar virtualmente complexa a decodificação do leitor. Um outro aspecto interessante é o de se obter, com o estudo, um quadro diferencial do desenvolvimento da ficção seriada brasileira no tocante à produção européia do período. Embora o humor estivesse lateralmente presente nos romances seriados franceses e ingleses, era central a exploração do modelo melodramático de narrativa. Embora 


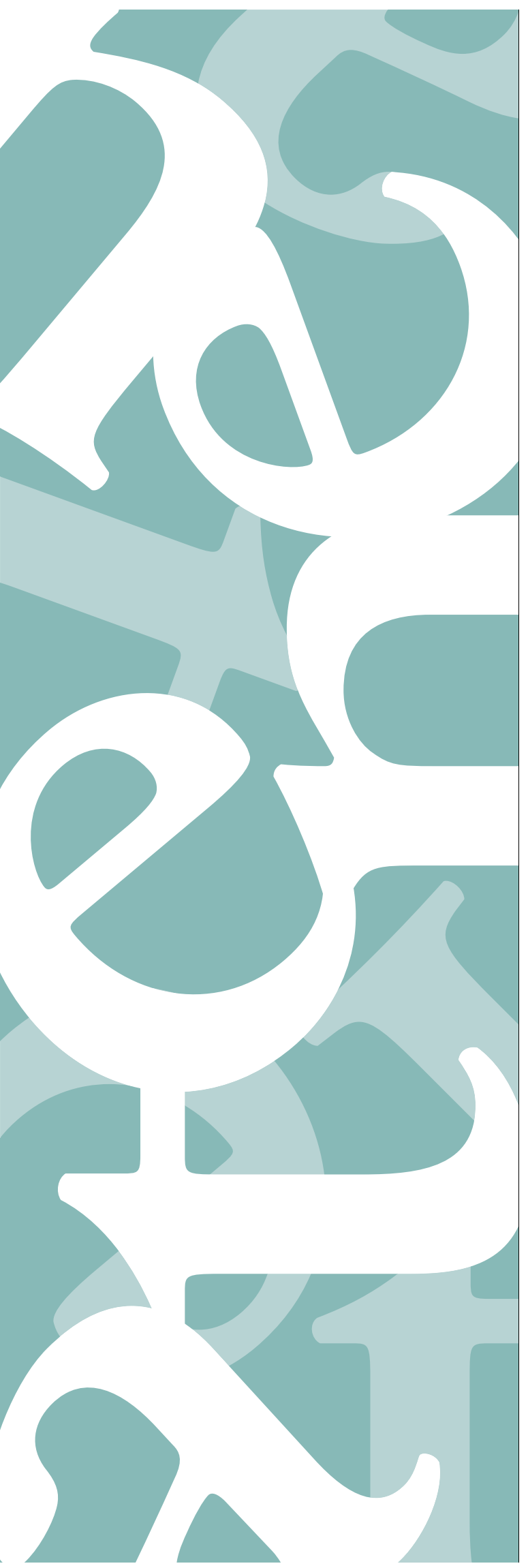

esse modelo tenha presença marcante na ficção brasileira, já no Romantismo nota-se uma exploração crescente da comicidade em autores tais como Joaquim Manuel de Macedo e Manuel Antônio de Almeida. Já no período do Realismo, a comicidade revela-se bem presente em vários autores que escreviam para a imprensa, entre eles, Machado de Assis, Raul Pompéia e Lima Barreto.

Em O Ateneu, a comicidade explorada pelo autor apóia-se substancialmente na ironia, que solicita uma decodificação ativa, crítica, de percepção engajada na construção do sentido do texto.

Arespeito dohumor, da comicidade e da ironia, é interessante destacar inicialmente alguns conceitos e constatações dos seguintes autores que se dedicaram à pesquisa sobre o assunto: Vladimir Propp e Maria Helena de Novais Paiva.

Propp (1992, pp. 28-30, 151-3) chega à conclusão, no seu estudo, de que, do ponto de vista da lógica formal, há dois tipos de riso, um que contém e outro que não contém a derrisão. O primeiro, com a derrisão, é o riso de zombaria, nele há a percepção de defeitos com ridicularização e escárnio; revela-se no riso de zombaria também a presença do sarcasmo, sendo esse tipo de riso a base da sátira. $\mathrm{O}$ segundo tipo é o riso bom, acompanhado por um sentimento de afetuosa cordialidade e simpatia na percepção dos pequenos defeitos, nele há a presença da alegria de viver. $\mathrm{O}$ autor indica que o humor é a capacidade de perceber e criar o cômico. Propp (1992, pp. 178-82) observa que a comicidade segue algumas leis. Uma delas é o aspecto de ser resultado de uma descoberta inesperada dos defeitos das pessoas ou das situações; outra lei é a brevidade, o riso de zombaria surge de uma revelação repentina de defeitos, ele irrompe como uma explosão de duração curta; uma terceira lei é o aspecto contagiante, pois as pessoas, por contágio, percebem “aquilo que não viam” e principiam a rir. O autor (Propp, 1992, p. 185) indica que nenhuma "teoria da sátira é possível fora de uma teoria do cômico que o considere seu instrumento essencial". 
Como método geral no trabalho com a comicidade na arte, percebe-se que Propp (1992, pp. 29-30) considera como fundamental a organização do material disponível de acordo com as causas que suscitam o riso, ou seja, “[...] do que riem [...] as pessoas e [...] o que é ridículo para elas [...]. Decorrente do primeiro procedimento é a classificação do material em função dos [...] procedimentos artísticos com os quais se suscita o riso [...]". Ao entrar, logo a seguir, na análise dos romances, terei em vista essas observações, pois irão ajudar a delinear os propósitos que expus no primeiro parágrafo do trabalho e a caracterizar quais processos de mecanismo de pensamento os textos ficcionais publicados na imprensa solicitavam do leitor.

Em seu estudo sobre a ironia na literatura, Paiva (1960, pp. 4-5) observa que a ironia dá base para um tipo de "processo para a criação do cômico" e que se pode percebê-la em seus efeitos, meio de "tornar risível determinada realidade". Pelo texto da autora (Paiva, 1960, p. 9), é evidente que a dissociação é um mecanismo fundamental que compõe o processo irônico, pois a palavra pára de ser a "expressão direta do pensamento" e sugere-o por antítese, tornando-se o seu antônimo. Para os interessados nos mecanismos de pensamento solicitados ao receptor do texto irônico, o estudo de Maria Helena de Novais Paiva é muito rico em informações. A autora pondera que a ironia é um processo de levar negativamente à verdade, realiza-se numa espécie de "prestidigitação do espírito", retirando disso a sua força expressiva, pois impõe ao receptor a obrigação de abandonar uma atitude passiva. $O$ texto irônico é analógico e exige um desdobramento para se tornar inteligível, impondo uma colaboração ativa àquele que o recebe. Maria Helena de Novais Paiva (1960, p. 10) indica, ainda, que é do processo ativo de recepção que se origina o alcance, a profundidade e a extensão de obras de "crítica social pela ironia".

Sobre a sátira, Paiva (1960, pp. 13-4) comenta que ela é uma forma de ironia e que o "aspecto de oposição ao meio" está na sua essência. Tem em vista que há na sátira, quase sempre, "um esforço de interpretação disfêmico-irônica", e que "não é necessário que o meio ambiente tenha algo de mau para satirizá-lo". A autora identifica dois aspectos presentes na sátira, que podem vir misturados. Um deles é a ironia resultante de uma deformação, o outro é a ironia que fixa a sua base na pintura exata do objeto e produz também o cômico. Interliga, por fim, o primeiro aspecto à natureza da paródia e da caricatura.

Maria Helena de Novais Paiva observa que é difícil definir com precisão a atitude interior desencadeada pela ironia; observa que resulta de constantes psicológicas que se graduam diferentemente e a diversificam em conceitos distintos que a traduzem parcialmente. Cita que, se nela predomina uma alegria amigável, individualiza-se em humor; quando se traduz uma amargura ácida, chama-se, então, sarcasmo; quando se joga agudamente com conceitos, chama-se espírito; se se alia ao burlesco, toma a forma de facécia; e quando se recorre à imitação, diferencia-se em sátira.

\section{A DISSOCIAÇ̃O IRÔNICA EM O ATENEU}

O processo de dissociação irônica faz-se perceptível do início ao final do romance. Tal processo liga-se às emoções contraditórias do personagem na sua relação simbólica com o colégio: rejeição e aceitação, amor e ódio. Aqui se revela novamente a exploração da técnica do suposto autor, a história é relatada pelo Sérgio já adulto. Essa técnica possibilita um enfoque pelo qual todos são incluídos no rebaixamento geral da visão satírica, inclusive o seu protagonista. No tocante à tradição irônica da exploração da técnica do suposto autor, nota-se um procedimento diferencial, uma espécie de transformação humanizadora no episódio quase final do despertar da atração de Sérgio por Ema. 


\section{Tom disfêmico-irônico}

O tom geral do relato é disfêmicoirônico. Os efeitos de rebaixamento e banalização, próprios da ironia disfêmica, concretizam o aspecto geral de inversão pelo qual passa a apresentação do universo do colégio. As relações humanas nos seus níveis biopsíquicos e socioculturais são focalizadas aqui microscopicamente.

Em $O$ Ateneu, nota-se uma arquitetura ficcional complexa, híbrida e original, na qual há a presença de uma comicidade ligada à ironia, técnicas ficcionais do padrão narrativo do romance seriado e aspectos da linguagem jornalística da época. Como criação romanesca, o escritor configura uma obra extremamente inovadora, que deixa aparentes os limites e as possibilidades de exploração do signo ficcional na imprensa.

\section{A VISUALIDADE E A COMICIDADE IRÔNICA COMO CAPTACÃO DA ATENÇÃO FLUTUANTE DO LETTOR}

Pierre Lévy (1993, p. 34) observa que o jornal e a revista são "bem adaptados a uma atitude de atenção flutuante ou de interesse potencial em relação à informação". Considero que a captação dessa atenção flutuante que guia o olhar do receptor-leitor sempre foi um elemento de peso e que influenciou decisivamente no momento da criação do texto jornalístico e da sua organização gráfica. Em O Ateneu, revela-se a presença de várias estratégias de captação desse olhar fugaz do leitor, que são resultantes, portanto, de um processo de criação ficcional para a recepção do leitor de jornal. Uma das estratégias faz-se perceptível na exploração contínua da caricatura. A outra estratégia evidencia-se na utilização de traços de representação artística próprios da linguagem visual, mais exatamente, da teoria visual do estilo impressionista. O gosto dos leitores da Gazeta de Notícias pelas imagens visuais era bastante conhecido e explorado pelos editores do jornal. Como chamariz para a renovação das assinaturas, o exemplar do dia 3 de janeiro de 1888 traz um anúncio na primeira página, em letras garrafais, que oferece um prêmio aos assinantes de "óleo graphias de Sealbert, Badnage” e de litografias mandadas buscar na Alemanha.

Numestudoaprofundado sobre o Impressionismo na pintura, Francastel (1974, pp. $62-4,87,160-5$ ) define os seguintes traços gerais da teoria visual dos impressionistas: registro visual de fenômenos de consciência e substituição das leis da experiência objetiva pelas da experiência subjetiva, interesse de criação ligado à inovação no terreno da realidade psicológica na sua união com o realismo formal, elaboração das sensações dadas pelos cinco sentidos, pintura fundada no registro das sensações com a substituição da perspectiva doespaço pela simples profundidade, visão de equivalências no processo decriação-busca de um equivalente plástico para cada sensação e emoção -, necessidade de analisar as sensações, gosto de fixação do efêmero e do fugidio - o instante ou o gesto que passam, papel fundamental da luminosidade, fixação dos aspectos fugitivos da vida, havendo recorrência ao jogo caprichoso das sombras, jogos de luzes, atração pela animação (seres em movimento e mecanismo dos gestos) -, distanciamento da escola naturalista em virtude da apresentação de um realismo de ordem espiritual. Completam o painel sobre os traços gerais da teoria visual impressionista as observações de Amado Alonso e de Claude Gandelman.

Alonso (1977, p. 112) indica que o texto verbal impressionista apresenta um certo "abandono da ordem lógica da frase". Gandelman (1986, p. 191) destaca que o Impressionismoé a hipóstase do olhar pousado sobre a tela no nível microscópico, e que somente o recuo do olhar do receptor pode recriar o olhar do pintor que dá, então, "sentido aos objetos" que se encontram ocultos ou velados por entre "as manchas da impressão".

Por meio da exploração da segunda grande temática do romance, ligada à pro- 
blemática da evolução do processo psíquico de individuação de Sérgio, materializa-se, no universo do romance, um proliferante conjunto de imagens de mundo, imagens típicas do estilo visual impressionista que citei há pouco. São imagens de mundo nas quais vêm impressas as projeções das emoções e sensações subjetivas vivenciadas por Sérgio. Destaca-se como centro produtor dessas imagens o movimento contraditório dos níveis de consciência de Sérgio no tocante à aceitação e rejeição simultâneas do mundo do colégio que é social e psiquicamente diferente da família. Comoexemplo do estilo impressionista cito, a seguir, vários trechos de seqüências que evidenciam um processo de construção que tem os seus alicerces ligados à teoria visual impressionista. Por meio de títulos e subtítulos, indico, a seguir, a função simbólica das imagens visuais produzidas. Comento em detalhes, no final, as passagens ligadas ao incêndio do Ateneu.

\section{Imagens fugidias de instantes $\mathrm{e}$ mecanismo dos gestos $(0$ jogo entre luzes e sombras). A luz como moldura simbólica do medo de Sérgio e expressão do poder de Aristarco}

Visão de Sérgio sobre o colégio ao voltar da festa de educação física:

"Na ocasião em que me ia embora, estavam acendendo luzes variadas de Bengala diante da casa. O Ateneu, quarenta janelas, resplendentes do gás interior, dava-se ares de encantamento com a iluminação de fora. Erigia-se na escuridão da noite, como imensa muralha de coral flamante, como um cenário animado de safira com horripilações errantes de sombra, como um castelo fantasma batido de luar verde emprestado à selva intensa dos romances cavalheirescos, despertado um momento

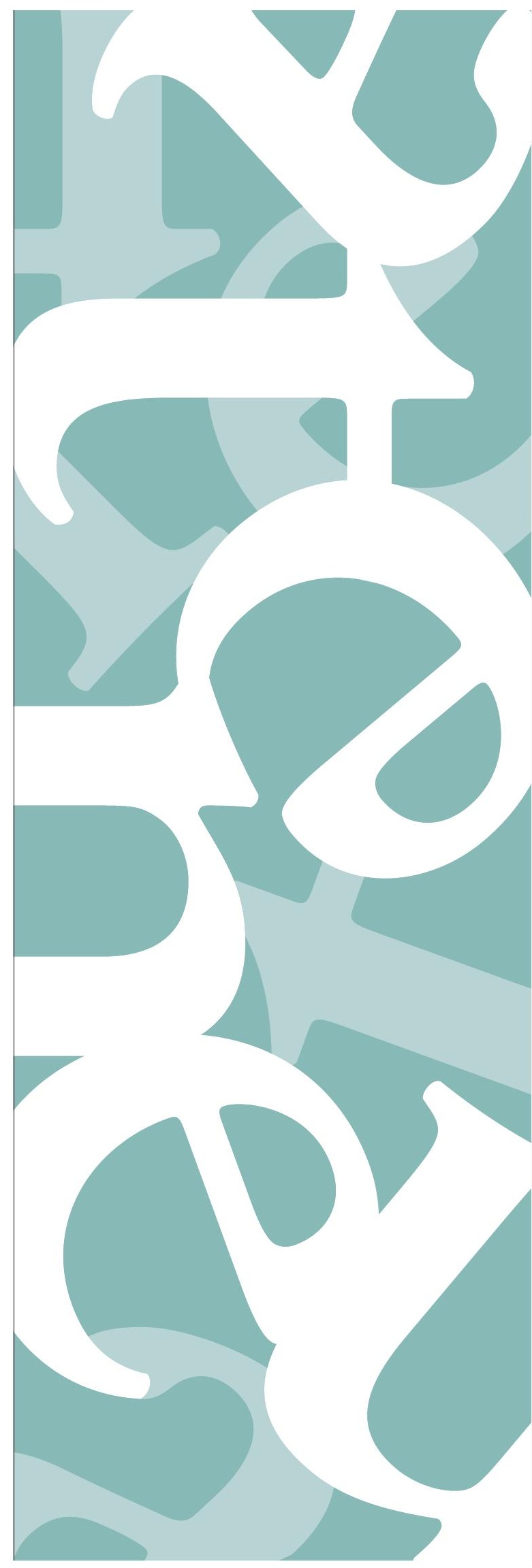


da legenda morta para uma entrevista de espectros e recordações. Um jacto de luz elétrica, derivado de foco invisível, feria a inscrição dourada - ATHENAEUM - em arco sobre as janelas centrais, no alto do prédio. A uma delas, à sacada, Aristarco mostrava-se. Na expressão olímpica do semblante transpirava a beatitude de um gozo superior. Devia ser assim: - luz benigna e fria, sobre bustos eternos, o ambiente glorioso do Panteão [...]. Guardei, na imaginação infantil, a gravura desta apoteose com o atordoamento ofuscado, mais ou menos de um sujeito partindo à meia-noite de qualquer teatro, onde, em mágica beata, Deus Padre pessoalmente se houvesse prestado a concorrer para a grandeza do último quadro" (Pompéia, 1979, pp. 18-9).

\section{Imagens efêmeras - níveis alegóricos - 0 jogo entre luzes e sombras: o fogo como símbolo da transmutação psíquica de Sérgio e da destruição do poder de Aristarco}

Percepção visual de Sérgio do incêndio do Ateneu:

“As chamas elevavam-se por cima do chalé, na direção do edifício principal. Imenso globo de fumo convulsionava-se nos ares, tenebroso da parte de cima, que parecia chegar ao céu, iluminado inferiormente por um clarão cor de cobre [...]. O susto de tal maneira me surpreendera, que eu não tinha exata consciência do momento. Esqueciame a ver os dragões dourados revoando sobre o Ateneu, as salamandras imensas de fumaça arrancando para a altura, desdobrando contorções monstruosas, mergulhando na sombra cem metros acima. [...] O fogo crescia ímpetos de entusiasmo, como alegrado dos próprios clarões, desfeiteando a noite com a vergasta das labaredas. [...] Por toda parte caíam escórias incineradas, que a atmosfera flagrante repelia para longe como folhas secas de imensa árvore sacudida. [...] Quando as bombas apareceram, desde muito tinham começado os desabamentos. [...] As alamedas, subitamente esclarecidas, multiplicavam as caras lívidas olhando. [...] Sobre as paredes internas que restavam, equilibravam-se pontas de vigamento, revestidas de um bolor claro de cinza, tições enormes, apagados. Na atmosfera luminosa da manhã flutuava o sossego fúnebre, que vem no dia seguinte sobre o teatro de um grande desastre" (Pompéia, 1979, pp. 146-7).

\section{Abandono da ordem lógica das frases}

Percepção visual de Sérgio do destino de Aristarco:

"Lá estava; em roda amontoavam-se figuras torradas de geometria, aparelhos de cosmografia partidos, enormes cartas murais em tiras, queimadas, enxovalhadas, vísceras dispersas das lições de anatomia, gravuras quebradas da história santa em quadros, cronologias da história pátria, ilustrações zoológicas, preceitos morais pelo ladrilho, comoensinamentos perdidos, esferas terrestres contundidas, esferas celestes rachadas; borra, chamusco por cima de tudo, despojos negros da vida, da história, da crença tradicional [...] planetas exorbitados de uma astronomia morta, sóis de ouro destronados e incinerados [...]. Ele, como um deus caipora, triste, sobre o desastre universal de sua obra" (Pompéia, 1979, p. 149).

\section{Visão de equivalências no processo de criação e registro das sensações e emoções}

Seqüência da natação: a movimentação e a mecânica dos gestos na piscina como símbolo do poder dos mais velhos sobre os 
mais novos; a desordem dos gestos como símbolo do medo de Sérgio da vida no colégio. Substituição da perspectiva do espaço pela simples profundidade.

“O fundo, invisível, de ladrilho oferecia uma inclinação, baixando gradualmente de um extremo para outro. [...] Por ocasião dos intensos calores de fevereiro e março e do fim do ano, havia aí dois banhos por dia. [...] turbulento debate de corpos nus, estreitamente cingidos no calção de malha rajado a cores, enleando-se os rapazes como lampreias, uns emergindo, reaparecendo outros, olhos injetados, cabelos a escorrer pela cara, vergões na pele de involuntárias unhadas dos companheiros, entre gritos de alegria, gritos de susto, gritos de terror; os menores agrupados no raso, dando-se as mãos em cacho, espavoridos, se algum mais forte chegava. Dos maiores, alguns havia que faziam medo realmente, singrando a braçadas, levando a ombro a resistência d'água; outros se precipitavam para baixo, volteando os pés no ar como cauda de peixe, prancheando sem ver a quem. $\mathrm{E}$, borbulhando entre os nadadores, fartas ondas de ressaca se emborcavam e iam transbordar e pelas imediações do banheiro alagando tudo.

Aolongo do tanque, corria o muro divisório, além do qual ficava a chácara particular do diretor. À distância, viam-se as janelas de uma parte da casa, onde às vezes eram recolhidos os estudantes enfermos, fechadas sempre as venezianas verdes" (Pompéia, 1979, pp. 32-3).

\section{Fixação dos aspectos fugitivos da vida com recorrência ao jogo caprichoso das sombras}

Museu do sono:

“Os colegas, tranquiilos, na linha dos leitos, afundavam a face nas almofadas, palejante da anemia de um repouso sem sonhos. Alguns afetavam um esboço de sorriso comovedor de sorriso ao lábio; alguns, a expressão desanimada dos falecidos, boca entreaberta, pálpebras entrecerradas, mostrando dentro a ternura embaciada da morte. De espaço a espaço, os lençóis alvos ondeavam do hausto mais forte do peito, aliviando-se depois por um desses longos suspiros da adolescência, gerados, no dormir da vigília inconsciente do coração. Os menores, mais crianças, conservavam uma das mãos ao peito, outra a pender da cama, guardando no abandono do descanso uma atitude ideal de vôo. Os mais velhos, contorcidos no espasmo de aspirações precoces, vergavam a cabeça e envolviam o travesseiro num enlace de carícias. [...] O gás, frouxamente, nas arandelas de vidro fosco, bracejando dos balões de asa de mosca, dispersava-se igual sobre as camas, doçura dispersa de um olhar de mãe. Que venturosa segurança naquele museu de sono!" (Pompéia, 1979, p. 54).

Essas passagens têm a função de envolver pela sua marcante visualidade a evolução e o desenlace do relato num conjunto de símbolos icônicos que funcionam como macrocélulas que sustentam a evolução da intriga.

A primeira imagem traz, comparativamente, as marcas do medo de Sérgio e expressa o narcisismo de Aristarco caracterizado pelo primeiro. Já a segunda imagem é, simbolicamente, um duplo ritual de exorcismo, sendo aqui evidente um processo de alegoria implícita. No nível psíquico, expressa a libertação de Sérgio do sistema de polaridades forçadas do colégio (para tudo formava-se a dois) e o seu despertar para a função sexual masculina. Lembre-se que a seqüência do incêndio é logo após o último encontro com Ema, mulher pela qual ele se sente atraído. Já no nível ideológico e político, é a destruição total do mundo monárquico de Aristarco, do seu sistema educacional, regido, sem dúvida, em última instância, pelo poder do dinheiro; por consequiência, tem-se também a destruição da própria monarquia. Recorde-se que as madeiras das arquibancadas da festa na qual comparecera a "Princesa Regente" é 
que dão corpo e vulto ao incêndio. Aqui se pode falar também na presença de biografemas ligados à visão política do autor real do romance, Raul Pompéia, que era republicano.

\section{Técnicas de construção ficcional que provocam o riso: os tracos visuais da caricatura na ficção verbal}

\section{Caricaturas.}

No processo de construção ficcional de $O$ Ateneu, nota-se uma forte presença da caricatura como técnica de criação de personagens. Há nessa recorrência à caricatura, a que já aludi, uma tentativa do escritor de captar a atenção flutuante do leitor de jornal. Na verdade, Raul Pompéia traz para o campo da linguagem verbal uma técnica de composição visual muito utilizada pelos pasquins do Segundo Império. Periódicos tais como A Semana Ilustrada, Revista Ilustrada, Vida Fluminense e $O$ Mosquito eram extremamente irreverentes e satíricos; distinguiam-se pela exploração de caricaturas de autoridades e personalidades de domínio público nas suas páginas. Por causa do tom satírico e irreverente, tais periódicos eram bastante conhecidos e consumidos. Havia, assim, a possibilidade de atrair o público desses periódicos.

Uma grande parte das personagens de $O$ Ateneu são construídas por meio da caricatura, aparecendo sob o prisma da ironia disfêmica e de sua conseqüente deformação.

\section{Traços de animais:}

\section{comparações canônicas e comparações metafóricas}

Os índices que caracterizam as personagens às vezes resultam da aplicação de características de animais aos homens. Inúmeras são as comparações canônicas (puras) ou comparações metafóricas. João Numa move-se com vivacidade de bácoro (porco) e o narrador relata que "O amável bácoro tomou-me pela mãoe descemos juntos". O Gualtério é miúdo e tem "motilidade brusca e caretas de símio". O Nascimento é "alongado por um modelo geral de pelicano”. O Negrão tem “fisionomia agreste de cabra". O Batista Carlos tem a "raça de bugre válido de má cara” (Pompéia, 1999, p. 33). Aristarco cofia os bigodes como "lambe o jaguar ao focinho a pregustação de um repasto de sangue" (Pompéia, 1999, p. 73). O Cerqueira tem o apelido de "Ratazana", é um sujeito cômico de "cara feita de beiços, rachada em boca como as romãs" e tem mãos grandes como "um disfarce de pés” (Pompéia, 1999, p. 144).

\section{Tracos deformantes}

Outros índices que caracterizam as personagens decorrem da seleção de traços singulares e inusitados. O Almeidinha tem "rosto de menina" e "faces de um rosa lânguido de convalescente", o Álvares tem sempre o "cenho carregado" e "cabeleira espessa" de vate (poeta) de taverna (Pompéia, 1999, p. 33). O Sanches tem os "lábios úmidos porejando baba" (Pompéia, 1999, p. 34). O Rômulo é conhecido pela alcunha de "Mestre Cook" e visto como um "besta, grandalhão", sendo o último na ginástica por causa da gordura (Pompéia, 1999, p. 47). O Franco é um pária, espécie de "velho anátema" mantido como "um bibelô do ensino intuitivo”. O Ribas é feio, magro, linfático, com "boca sem lábios de velha carpideira”. A banca examinadora do final de curso recebe o mesmo tipo de caracterização. O professor Meireles é o "compridão de barbas" (Pompéia, 1991, p. 141). O professor Simas é "um pançudo" que tem o apelido de "Esfera Terrestre" (Pompéia, 1999,p. 141). Outros professores não recebem nome, como o sexagenário, que é encanecido e helicoidal (forma de hélice) e tem a "cara lambida de padre" (Pompéia, 1999, p. 191). 


\section{Composição hiperbólica e paradoxista}

Em Aristarco pode-se falar numa construção hiperbólica que se apóia no paradoxismo. Verifica-se, nesse processo de construção, a potenciação de índices de significação oposicional. Por meio dessa estratégia literária, evidencia-se a dupla face de sacerdote da educação e gerente atento ao pagamento das mensalidades, de juiz implacável e corruptor dos próprios regulamentos que cria, deus olímpico e ditador, pai extremoso e padrasto. Veja-se, a seguir, um típico segmento exemplificativo desse modo de construção na primeira seqüência do Capítulo II:

"Abriam-se as aulas a 15 de fevereiro. [...] Aristarco, que consagrava as manhãs ao governo financeiro do colégio, conferia, analisava os assentamentos do guarda-livros. De momento a momento entravam alunos. Alguns acompanhados.

Acada entrada, o diretor lentamente fechava o livro, marcando a página com um alfanje de marfim; fazia girar a cadeira e soltava interjeições de acolhimento, oferecendo episcopalmente a mão peluda ao beijo filial dos meninos. Os maiores, em regra, recusavam-se à cerimônia e partiam com um simples aperto de mão.

A cadeira girava de novo à posição primitiva; o livro da escrituração espalmava outra vez as páginas enormes; e a figura paternal do educador desmanchava-se, volvendo a simplificar-se na esperteza atenta e seca do gerente" (Pompéia, 1999, pp. 27-8).

É um tipo de criação cômica de longa tradição na ficção européia e brasileira.

\section{Transposições cômicas}

Paiva (1960, p. 131) observa que a transposição é "uma das fontes mais ricas do cômico”; provoca uma sensação de imprevisto e consiste no processo de

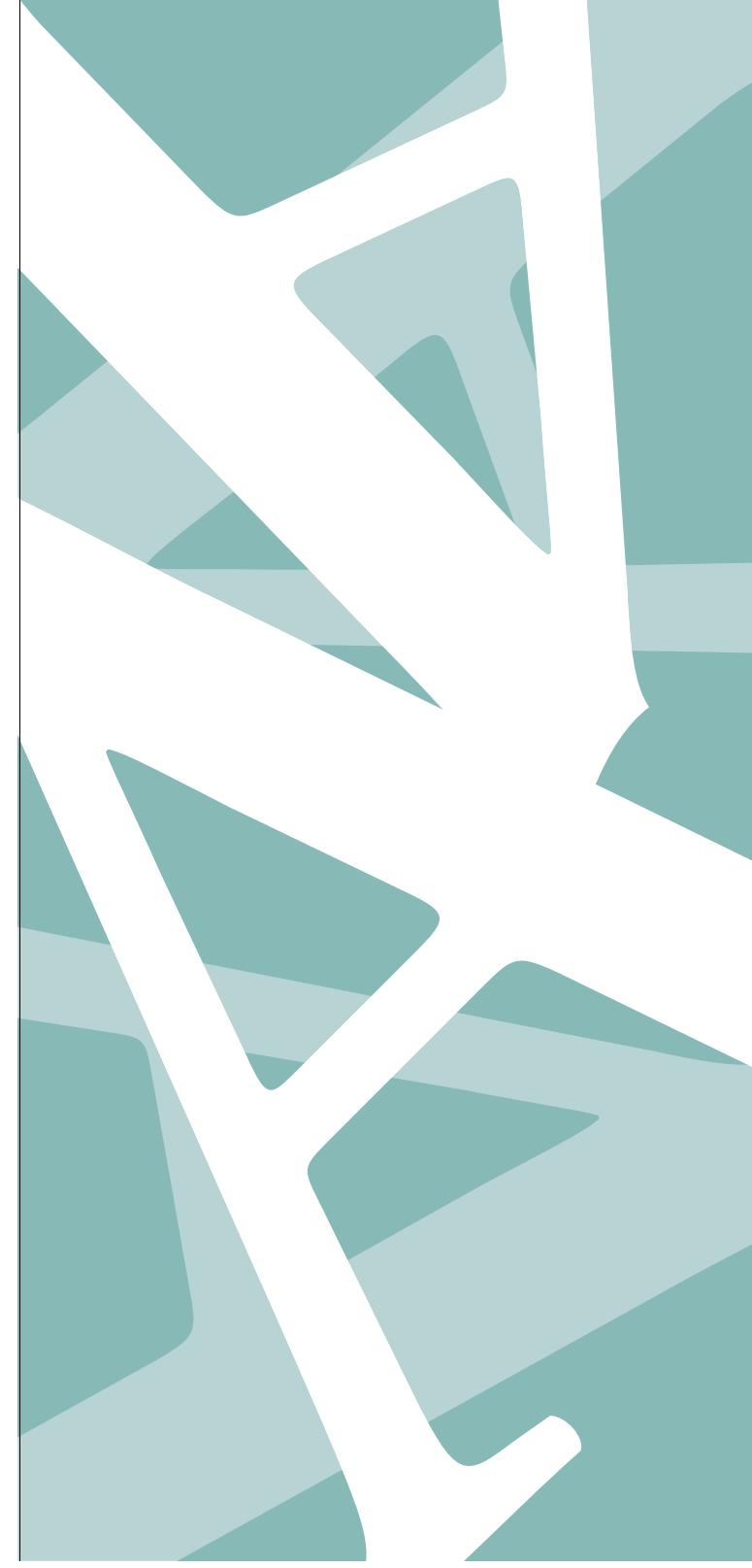

deslocar uma realidade do "plano que lhe é próprio para outro, de forma a destacar a impropriedade da transposição". A autora (Paiva, 1960, p. 131) considera que, por um lado, nisso se reúne "o sentimento do deslocado" e, por outro lado, a "capacidade expressiva da transposição”. Paiva lembra também que o riso surge ligado a qualquer aspecto que "não se integra no seu conjunto", mantendo-se como que "exterior a ele, corrompendo-lhe a unidade" e funcionando como "um germe de desagregação", pois tal aspecto é de "natureza diferente dos outros". Em O Ateneu, há a exploração de transposições cômicas. Por exemplo, Aristarco aparece com o comportamento de um deus olímpico para no final ser transfigurado em deus caipora. Bento Alves e Sérgio, de bons amigos, passam a representar a "comédia 
colegial dos sexos" (Pompéia, 1999, p. 167), expressão esta utilizada pelo segundo personagem. O professor Venâncio louva o azul do céu e o sol, apesar da chuva torrencial no episódio do passeio pelo Jardim Botânico (Capítulo VIII).

Auxilia o processo de criação das transposições cômicas a presença de alusões intertextuais, que aumenta os aspectos jocosos das personagens. Para caracterizar o ar de divindade assumido habitualmente por Aristarco, é dito que ele vestia um manto transparente da mesma natureza do tecido leve de brisas trançadas de Théophile Gautier (Pompéia, 1999, p. 72). Nearco da Fonseca, cuja magreza é visível, é apresentado como o próprio Charles Blondin, um célebre ginasta francês do século XIX.
Para finalizar é importante dizer que Raul Pompéia compõe um romance impressionista e híbrido quanto ao processo de criação, pois não se enquadra nem no modelo clássico da ficção realista, nem no modelo determinista do texto naturalista. $\mathrm{O}$ autor utiliza-se de técnicas de criação ligadas à atmosfera da linguagem jornalística e do gosto do leitor ligado a outras séries artísticas, entre elas, as artes visuais. Por meio de todas essas estratégias no processo de criação do romance, Raul Pompéia solicita um tipo de leitura ativa e participativa. Sua experiência de escritor para a Gazeta de Notícias apresenta a mesma grandeza de inovação que autores como Edgar Allan Poe e Charles Dickens revelaram ao criar ficção para a imprensa periódica.

\section{BIBLIOGRAFIA}

ABRAHMS, J. Ao Encontro da Sombra. Tradução Merle Scoss. São Paulo, Cultrix, 1998.

ARRIGHI, G. O Longo Século XX: Dinheiro, Poder e as Origens de Nosso Tempo. Tradução Vera Ribeiro. Rio de Janeiro/ São Paulo, Contraponto/Edunesp,1996.

BAKHTIN, M. Esthétique et Théorie du Roman. Paris, Gallimard, 1987. Esthétique de la Création Verbal. Paris, Gallimard, 1991.

. Questões de Literatura e de Estética. Tradução Aurora Fornoni Bernardini. São Paulo, Hucitec/Edunesp, 1993. BAKHTIN, M.; MEDVEDEV, P. N. The Formal Methode in Literary Scholarship. Translated by Albert J. Wehrle. Baltimore

and London, The Johns Hopkins University Press, 1991.

BENDER, I. C. Comédia e Riso: uma Poética do Teatro Cómico. Porto Alegre, UFRGS/EDPUCRS, 1996.

BENJAMIN, W. "0 Autor como Produtor", in Magia e Técnica, Arte e Política. Tradução Sérgio Paulo Rouanet. São

Paulo, Brasiliense, 1986.

B00TH, W. C. A Rhetoric of Irony. London, The University of Chicago Press, 1974.

BRANDÃO, R. Figuras de Linguagem. São Paulo, Ática, 1995.

CANCLINI, N. G. Culturas Híbridas: Estrategias para Entrar y Salir de la Modernidad. México, Grijalbo, 1990.

DECOTTIGNIES, J. Écritures Ironiques. Lille, Presses Universitaires de Lille, 1988.

DIEM, J. M. Le Sens de I'Humour. Paris, Denoël, 1987.

DUBOIS, J. et alii. Retórica Geral. Tradução Carlos Felipe Moisés et alii. São Paulo, Cultrix/Edusp, 1975.

ECO, U. The Role of the Reader. Bloomington, Indiana University Press, 1979.

FEATHERStONE, M. Cultura de Consumo e Pós-modernismo. Tradução Julio Assis Simões. São Paulo, Studio Nobel, 1995.

FERNANDES, I. Memória da Telenovela Brasileira. 3 ed. São Paulo, Brasiliense, 1994.

FERRAZ, M. de L. A. A Ironia Romântica: Estudo de um Processo Comunicativo. Lisboa, Imprensa Nacional/Casa da

Moeda, 1987.

FRANCASTEL, E. O Impressionismo. Lisboa, Edições 70, 1974.

GANDELMAN, C. Le Regard dans le Texte. Paris, Méridiens-Klincksiec, 1986.

GO0DMAN, N. Languages of Art; an Aproach to the Theory of Symbols. Indiannapolis, Hackett, 1976. 
HIGHET, G. The Anatomy of Satire. Princenton, Princeton University Press, 1962.

ISER, W. The Act of Reading: a Theory of Aesthetic Response. London, The Johns Hopkins Press, 1980.

JAKOBSON, R. Lingüistica e Comunicação. Tradução Izidoro Blikstein e José Paulo Paes. São Paulo, Cultrix, 1995.

JANKÉLÉVITCH, V. L'Ironie. Paris, Flammarion, 1964.

JAUSS, H. R. Pour une Esthétique de la Réception. Traduit de par Claude Maillard. Paris, Gallimard, 1978.

JUNG, C. G. Presente e Futuro. Tradução Maria de Sá Cavalcante. Rio de Janeiro Vozes, 1974.

. O Eu e o Inconsciente. 11 1e ed. Petrópolis, Vozes, 1987.

A Energia Psíquica. 5a ed. Petrópolis, Vozes, 1994.

LÉVY, P. As Tecnologias da Inteligência: o Futuro do Pensamento na Era da Informática. Tradução Carlos Irineu da Costa.

Rio de Janeiro, Editora 34, 1993.

LOTMAN, I. M. Universe of the Mind: a Semiotic Theory of Culture. Translated by Shukman. Bloomington and Indianopolis, Indiana University Press, 1990.

MORIN, E. L'Esprit du Temps. Paris, Gallimard, 1986.

. La Méthode 4: les Idées. Paris, Sevil, 1991.

PAIVA, M. H. de. Contribuição para uma Estilistica da Ironia. Lisboa, Centro de Estudos Portugueses, 1960.

POMPÉIA, R. O Ateneu, Crônica de Saudades, in Gazeta de Notíicias, Rio de Janeiro, abr./jun./1888.

. 0 Ateneu. $3^{a}$ ed. Rio de Janeiro, F. Alves, s/d.

O Ateneu. 6a ed. São Paulo, Ática, 1979.

O Ateneu. São Paulo, L\&PM, 1999.

PROPP, V. Comicidade e Riso. Tradução Aurora Fornoni Bernardini e Homero Freitas de Andrade. São Paulo, Ática, 1992.

RECTOR, M. Comunicação na Era Pós-moderna. Petrópolis, Vozes, 1997.

RIBEIRO, J. A. Imprensa e Ficção no Século XIX: Edgar Allan Poe e a Narrativa de Arthur Gordon Pym. São Paulo,

Edunesp, 1996.

RIOUT, D. Les Ecrivains Devant L'Impressionisme. Paris, Macula, 1989.

SCHNAIDERNAN, B. "Sobre Algumas Dificuldades de Princípio na Descrição Estrutural de um Texto", in I. M. Lotman,

Semiótica Russa. Tradução Aurora F. Bernardini. São Paulo, Perspectiva. 1979.

SODRÉ, N. W. História da Imprensa no Brasil. São Paulo, M. Fontes, 1983.

THOMPSON, J. B. Ideologia e Cultura Moderna: Teoria Social Crítica na Era dos Meios de Comunicação de Massa.

Tradução Grupo de Estudos sobre Ideologia, Comunicação e Representações Sociais da pós-graduação do Instituto

de Psicologia da PUC-RS. Petrópolis, Vozes, 1995.

WILBER, K. O Espectro da Consciência. São Paulo, Cultrix, 1995. 